\title{
Análise dos Projetos Pedagógicos dos Cursos de Licenciatura em Química Paranaenses: As Compreensões Tecidas à Luz do Enfoque CTSA
}

\section{Analysis of the Pedagogical Projects of Chemistry Education Courses in the State of Paraná: Comprehensions Developed in the Light of the STSE Approach}

\author{
Rosilene dos Santos Oliveira \\ Brasil \\ Neide Maria Michellan Kiouranis \\ Brasil
}

O contexto atual de intensas mudanças sociais e ambientais, decorrentes do desenvolvimento científico e tecnológico, apresenta como um de seus desafios a necessidade de propiciar a formação de profissionais para o exercício pleno da cidadania, participação em processos de tomadas de decisões, compreensão das relações entre Ciência, Tecnologia, Sociedade e Ambiente (CTSA), o que requer um novo posicionamento dos sujeitos. São aspectos que se coadunam com os objetivos do enfoque CTSA e devem permear os cursos de Licenciatura em Química. Desse modo, a presente pesquisa tenciona investigar como o enfoque CTSA tem sido contemplado e incorporado nos Projetos Pedagógicos de Cursos (PPC) de Licenciatura em Química das Instituições públicas de Ensino Superior localizadas no estado do Paraná. Para tanto, procedemos à análise desses documentos conforme os pressupostos da Análise Textual Discursiva (ATD). Da análise propriamente dita, identificamos aspectos como: formação para a cidadania; responsabilidade ética, social e/ou ambiental; atuação crítica, emancipadora e transformadora da realidade, os quais consistem em elementos do enfoque CTSA no direcionamento de uma formação humanística. Isso nos leva a compreender que os cursos de Licenciatura em Química analisados neste estudo reconhecem a importância de tal formação, pois o profissional docente deve ser formado com embasamento nos conhecimentos técnico-científicos e valores humanos, mas também para o entendimento da função social e política de sua profissão, de modo a se reconhecer enquanto profissional cidadão.

Palavras-chave: formação inicial de professores; cursos de Química; cidadania.

The current context of intense social and environmental changes, resulting from scientific and technological development, poses a challenge in the sense that the society needs to provide training for professionals for the full exercise of citizenship, participation in decision-making processes, understanding of the relationships between Science, Technology, Society and 
Environment (STSE), which demands a novel way of thinking from people. These aspects are consistent with the objectives of the STSE approach and should permeate Chemistry Education Courses. In this way, this research aims to investigate how the STSE approach has been contemplated and incorporated in the Pedagogical Course Projects (PCP) of Chemistry Education Programs at public Institutions of Higher Education located in the State of Paraná, Brazil. For that, we carried out an analysis of these documents according to the assumptions of the Discursive Textual Analysis (DTA). From the analysis itself, we identified aspects such as training for citizenship; ethical, social and/or environmental responsibility; critical, emancipatory and transforming reshape of reality, which are all elements related to the STSE approach that lead to a humanistic training. The results guide us to understand that the Chemistry Education Courses analyzed in this study perceive the importance of this kind of training, as the teacher not only must be trained based on technical-scientific knowledge and human values, but also has to comprehend the social and political function of teaching, in order to be recognized as a professional citizen.

Keywords: teacher education; Chemistry education courses; citizenship.

\section{Reflexões iniciais}

Os avanços científicos e tecnológicos se expandem de maneira que, ao mesmo tempo em que são capazes de nos proporcionar conforto, bem-estar e até mesmo longevidade, também podem acarretar graves impactos ambientais e sociais, regidos, principalmente, por interesses políticos e econômicos. Nesse contexto, expande-se também a necessidade de os cidadãos aprofundarem o entendimento acerca das relações entre Ciência, Tecnologia, Sociedade e Ambiente (CTSA) ${ }^{1}$, que, por sua vez, consistem em elementos constitutivos da sua realidade, exigindo-lhes novos posicionamentos.

Neste sentido, desde a década de 1970, o enfoque CTS (Ciência, Tecnologia e Sociedade) tem orientado currículos de diferentes níveis de ensino em distintos países, com o intuito de formar cidadãos alfabetizados científica e tecnologicamente, capazes de questionar e participar no processo de tomadas de decisões de maneira crítica, reflexiva e responsável (Santos, 2007). Pretende-se, assim, envolver a sociedade para participar democraticamente das decisões relacionadas ao desenvolvimento científico e tecnológico, rechaçando as decisões tecnocráticas, isto é, as decisões tomadas exclusivamente por especialistas. Além disso, consideram-se os inúmeros fatores externos que influenciam nesse desenvolvimento, o qual, muitas vezes, privilegia grupos dominantes e, consequentemente, legitima a manutenção do status quo.

\footnotetext{
1 A sigla CTSA tem sido adotada e defendida por alguns pesquisadores desde o ano de 2010, em decorrência de discussões relacionadas às questões ambientais ocorridas no II Seminário Ibero-Americano de Ciência-TecnologiaSociedade no Ensino das Ciências (II SIACTS-EC). Dentre estes pesquisadores citamos Vilches, Gil-Pérez e Praia (2011), os quais defendem que “[...] aqueles que promovem a expressão CTSA não estão dizendo que a "A" não esteja contida em CTS, mas antes pretendem que se lhe dê uma maior ênfase na educação científica para evitar um tratamento particularmente insuficiente das questões ambientais quando se incorporam as relações CTS” (p. 180). Em concordância com esse posicionamento, adotamos em nossos estudos o termo CTSA, respeitando os autores que optam por utilizar o acrônimo CTS, o qual em algumas citações ao longo de nosso texto foi mantido, como por exemplo, no caso de Auler, Santos, Mortimer, Vieira, Tenreiro-Vieira e Martins.
} 
No que se refere ao contexto brasileiro, desde 1970, o enfoque CTS esteve presente em discussões pontuais nos meios acadêmicos e outros contextos educacionais, sendo explicitado pela primeira vez na década de 1990, por meio dos Parâmetros Curriculares Nacionais do Ensino Fundamental e Médio, se expandindo posteriormente com a produção de pesquisas, materiais didáticos, eventos e proposição de cursos (Santos, 2007). Além disso, como apontado em uma pesquisa realizada por Strieder, Silva, Fernandes Sobrinho e Santos (2016), o enfoque CTS possui respaldo nos documentos oficiais brasileiros que orientam a ação pedagógica dos professores da Educação Básica, embora as abordagens identificadas necessitem de aprofundamento crítico. Cortez e Del Pino (2018), ao investigarem a relação entre as Diretrizes Curriculares Nacionais para os Cursos de Licenciatura em Ciências da Natureza (Ciências Biológicas, Física e Química), de 2001 e a de 2015, e o enfoque CTS, evidenciaram consonância entre estes, uma vez que alguns aspectos, como a contextualização, a interdisciplinaridade, a formação crítica e ética direcionada para o exercício da cidadania, são contemplados nesses documentos e no referido enfoque.

Ante o exposto, consideramos que o espaço educacional se constitui como o mais propício para uma formação que atenda aos objetivos do enfoque CTSA, o que inclusive é respaldado por documentos oficiais. No entanto, para que o professor possa atuar nesse contexto, faz-se necessário que, em sua formação inicial, encontre subsídios que lhe possibilite desenvolver sua atividade educativa nesta perspectiva. Isso requer a congruência entre o currículo prescrito, regido pelos documentos oficiais, e o currículo real, o qual se realiza efetivamente na sala de aula (Calixto, 2019), de modo a promover o isomorfismo na formação de professores, ou seja, a aproximação entre o tipo de formação ofertada com a que é exigida em sua prática profissional (Niza, 1997; MarceloGarcía, 1999; Calixto, 2019).

Nesse contexto, a produção de pesquisas relacionadas ao enfoque CTSA na formação inicial de professores de Química tem se voltado para o ensino de Ciências no sentido de discutir ações e possibilidades que possam promover a diminuição da distância existente entre o que se encontra estabelecido em documentos curriculares e sua implementação em sala de aula. Tais pesquisas apresentam uma diversidade de focos, os quais perpassam desde a análise de documentos orientadores dos cursos de Licenciatura em Química, como Diretrizes Curriculares, Projetos Pedagógicos de Curso (PPC), estrutura curricular e ementas, até intervenções pedagógicas, elaboração de materiais didáticos, produção de sequências didáticas e reelaboração de práticas experimentais no contexto do espaço de formação inicial. O que, por sua vez, denota a preocupação com a formação de professores que dominem para além dos conhecimentos científicos específicos de sua área, o que implica a necessidade de formação sólida, ampla e humanística, que abranja as inter-relações entre Ciência, Tecnologia, Sociedade e Meio Ambiente.

Nessa perspectiva, ao realizarmos um levantamento das pesquisas brasileiras, no catálogo de Teses e Dissertações da Coordenação de Aperfeiçoamento de Pessoal de 
Nível Superior (CAPES), no período de 1987 a 2018, que articulam a formação inicial de professores de Química e o enfoque CTS identificamos um total de 23 pesquisas (15 Dissertações e 8 Teses), e destas somente 6, de alguma maneira, investigam ou analisam o currículo de cursos de Licenciatura em Química em articulação com o enfoque CTS(A), direcionando-se ao Projeto Pedagógico de Curso, a ementa ou a matriz curricular, a saber: Figueiredo (2011), investigou se os fundamentos teóricos do enfoque CTSA eram contemplados no referido curso, considerando os componentes curriculares e suas cargas horárias dispostos em seu currículo, além de identificar as concepções dos licenciandos e desenvolver juntamente a estes uma oficina temática pautada no enfoque CTSA; Moreno Rodríguez (2015), pesquisou dois cursos de duas universidades, sendo uma brasileira e outra colombiana, por meio de análise documental e entrevistas com os coordenadores; Silva (2016a), investigou as limitações e potencialidades presentes em uma proposta de ensino direcionada ao componente curricular "Ciência, Tecnologia e Sociedade (CTS)" e analisou o PPC; Silva (2016b), realizou uma pesquisa documental acerca da inserção de questões ambientais em dois cursos e a entrevista com os coordenadores e professores de cada um deles, de modo que o enfoque CTSA emergiu das respostas dos entrevistados em consonância com aspectos presentes no PPC; Santos (2017) em sua investigação analisou a matriz curricular do curso, bem como as concepções dos licenciandos acerca da tríade CTS e do ensino nesse viés e; Brandão (2018), investigou a questão ambiental por meio da experimentação atrelada ao enfoque CTS, em análise de PPC. Esses exemplos se constituem um número ainda tímido de pesquisas que investigam os documentos orientadores dos cursos de Licenciatura em Química, considerando que desde a década de 1990 vem sendo realizadas discussões e inclusive a inserção do referido enfoque em documentos oficiais.

Sinalizamos que as referidas pesquisas além de realizarem alguma análise em relação aos documentos de um determinado curso de Licenciatura em Química, também se utilizam de entrevistas com licenciandos, professores e/ou coordenadores, em outros verificamos ainda a proposição de atividades de implementação, como por exemplo, a elaboração e aplicação de oficinas atreladas ao enfoque CTSA. Os resultados destas pesquisas nos indicam que os PPC encontram-se consoantes com os documentos oficiais, sinalizam ainda para a necessidade de serem desenvolvidas nesses cursos atividades que possibilitem a implementação do enfoque CTSA em sala de aula, bem como ampliação da carga horária e de espaços nos cursos para discussões envolvendo as relações entre Ciência, Tecnologia, Sociedade e Ambiente, de modo a possibilitar a convergência entre os conhecimentos químicos e o referido enfoque e a desmistificação de concepções simplistas em relação à tétrade CTSA. Além disso, pontuam à necessária aglutinação entre as propostas e as práticas que se desenvolvem nesses cursos. Diante desse contexto, valorizamos tais pesquisas e reconhecemos sua importância, uma vez que podem nos dar direcionamentos quanto à aproximação entre o currículo prescrito e o currículo real. No entanto, defendemos também a necessidade de compreender com profundidade como os documentos orientadores da formação inicial de professores de 
Química têm contemplado em sua amplitude o enfoque CTSA e assim perscrutar os espaços que podem promover sua possível incorporação.

Dessa forma, reconhecendo que os currículos, em consonância com os documentos legais, orientam os cursos de formação de professores e a ação pedagógica docente, apresentamos nossa investigação, a qual consiste em um recorte de uma pesquisa, em nível de mestrado, defendida no ano de 2020, com o objetivo de compreender como o enfoque CTSA tem sido contemplado nos currículos dos cursos de Licenciatura em Química das Instituições públicas de Ensino Superior paranaenses. Neste sentido, nos documentos analisados, identificamos aspectos referentes à: alfabetização científica e tecnológica; natureza da Ciência; interdisciplinaridade; contextualização; problematização; componentes curriculares e conteúdos CTSA; formação para a cidadania; compromisso ético, social e ambiental, os quais articulam, cada um dos três metatextos emergentes da análise, a saber: 1) Direcionamento para a formação humanística no entretecer da formação de professores de Química e o enfoque CTSA; 2) Formação direcionada ao enfoque CTSA e suas relações com a alfabetização científica e tecnológica e compreensão acerca da natureza da Ciência e; 3) Operacionalização do enfoque CTSA no currículo.

Em vista do contexto mencionado, e, considerando que o presente estudo constitui-se parte de uma pesquisa mais ampla, neste espaço serão abordados somente os entendimentos referentes aos aspectos que nos direcionaram à formação humanística, a fim de possibilitar o aprofundamento que o assunto merece em busca de novas compreensões acerca do objeto de estudo. Formação esta que desponta do entendimento da necessidade de propiciar uma formação profissional para além dos aspectos técnicocientíficos, englobando, intrinsecamente, o exercício da cidadania, a tomada de decisão em processos decisórios locais e globais, a autonomia de pensamento, os valores éticos e humanos, a responsabilidade socioambiental e o reconhecimento da função social e política da profissão docente.

\section{Formação inicial de professores de Química e o enfoque CTSA: uma articulação necessária}

Estudos têm apontado para a necessidade de se incorporar o enfoque CTS na formação de professores (Acevedo-Díaz, 1996; Auler, 2002; Azevedo, Ghedin, SilvaForesberg, \& Gonzaga, 2013; Magalhães \& Tenreiro-Vieira, 2006; Moreno Rodríguez, 2015; München, 2016; Nunes, 2010; Trivelato, 1999; Vieira \& Martins, 2005; Silva, Almeida, Nascimento, \& Prudêncio, 2019). Isso se deve ao reconhecimento da importância em propiciar uma formação científica para o exercício pleno da cidadania; participação ativa dos cidadãos em processos de tomadas de decisões envolvendo questões referentes ao desenvolvimento científico e tecnológico, em detrimento do modelo de decisões tecnocráticas; compreensão das implicações sociais e ambientais advindas desse desenvolvimento; rechaço da imagem de Ciência pura e neutra, assim como da Tecnologia enquanto Ciência aplicada (Auler, 2002; López Cerezo, 1998).

Esses objetivos visam a uma formação que transcenda a preparação profissional, 
se estendendo à formação humanística e contextualizada, e que possibilite "[...] uma perspectiva de estruturação da Ciência em interação com a Tecnologia e com a Sociedade, no sentido de desenvolver uma visão holística e integradora da Ciência" (Vieira, TenreiroVieira, \& Martins, 2011, p. 14), tornando-a “[...] relevante para a vida dos estudantes" (Vieira et al., 2011, p. 15). Assim, o intuito é o de que estes sejam capazes de atuar na análise e resolução de problemas que despontam de sua realidade em articulação com os conhecimentos adquiridos.

A esse respeito, Auler (2007) menciona que “[...] tentar resolver um problema, desvinculando-o das relações sociais em que se configura, de forma apenas técnica, via aumento de conhecimentos técnico-científicos, pode significar um retorno à tecnocracia" (p. 7). Ou seja, ao serem desconsideradas essas questões, se tolhe a participação pública nas decisões referentes à Ciência e a Tecnologia (CT), deixando-as exclusivamente nas mãos dos ditos especialistas, o que reacende o mito da superioridade/neutralidade das decisões tecnocráticas em detrimento das decisões democráticas.

Além disso, a articulação entre a CT pode contribuir para a elaboração de novos conhecimentos, o que, por sua vez, rechaça a concepção de Tecnologia enquanto Ciência aplicada e de conhecimento científico como um produto acabado (Vieira et al., 2011). Esses autores apontam ainda que os processos inerentes ao conhecimento científico podem auxiliar na formulação de juízos de valor referentes a situações-problemas que se desenrolam na trama da vivência cotidiana com o mundo.

Disso percebemos a importância de se apresentarem os elementos da construção do conhecimento científico, o qual emerge em meio à integração de vários fatores externos, como aspectos e interesses políticos, sociais, econômicos, culturais, ambientais, entre outros. Nessa perspectiva, auxilia na desmistificação da concepção de uma CT neutra, dogmática, construída por grandes gênios e cujo desenvolvimento se direciona no sentido unilateral do bem-estar social.

Nesse sentido, a educação CTSA em sua totalidade

[...] permite ir mais além do que o mero conhecimento acadêmico da Ciência e da Tecnologia, preocupando-se com os problemas sociais relacionados com questões do foro científico e tecnológico, bem como uma melhor compreensão das interações da Ciência, Tecnologia e Sociedade. Como proposta educativa inovadora, constitui um novo planeamento do currículo em todos os níveis de ensino, com a principal finalidade de promover competências, envolvendo conhecimentos, capacidades e valores. Trata-se de formar sujeitos autônomos que confiem nas suas próprias capacidades e nas dos outros para propor alternativas e atuar de modo a contribuir para construir uma sociedade mais justa e sustentável, para hoje e para o futuro (Vieira et al., 2011, p. 16, grifo nosso).

Como enfatizado por esses autores, percebemos que a educação CTSA apresenta em seu cerne uma profunda preocupação em relação às implicações sociais e ambientais acarretadas pela CT e pela inter-relação destas com a sociedade e vice-versa. No que se refere à sua presença em desenhos curriculares, se destaca por abranger todos os níveis 
de ensino, desde o Ensino Básico até o Superior, de modo a propiciar o desenvolvimento de competências e a formação de sujeitos autônomos, responsáveis e críticos, aptos a tomarem decisões em busca da promoção da justiça social e da sustentabilidade (Vieira et al., 2011).

Em consonância com o exposto, voltamo-nosagora para algumas das competências gerais da Educação Básica apresentadas pela Base Nacional Comum Curricular (BNCC), as quais devem ser desenvolvidas nos educandos ao longo de sua trajetória escolar, “[...] articulando-se na construção de conhecimentos, no desenvolvimento de habilidades e na formação de atitudes e valores, nos termos da LDB” (MEC, 2018, p. 9). Dentre elas, a BNCC estabelece:

7. Argumentar com base em fatos, dados e informações confiáveis, para formular, negociar e defender ideias, pontos de vista e decisões comuns que respeitem e promovam os direitos humanos, a consciência socioambiental e o consumo responsável em âmbito local, regional e global, com posicionamento ético em relação ao cuidado de si mesmo, dos outros e do planeta.

\section{$[\ldots]$}

10. Agir pessoal e coletivamente com autonomia, responsabilidade, flexibilidade, resiliência e determinação, tomando decisões com base em princípios éticos, democráticos, inclusivos, sustentáveis e solidários (MEC, 2018, p. 9, grifos nossos).

Ao que se refere, especificamente, à área das Ciências da Natureza e suas Tecnologias destacamos o direcionamento presente na BNCC ao considerar "[...] que aprender Ciências da Natureza vai além do aprendizado de seus conteúdos conceituais" (MEC, 2018, p. 547), requerendo também a "[...] contextualização social, histórica e cultural da ciência e da tecnologia [...] para que elas sejam compreendidas como empreendimentos humanos e sociais" (MEC, 2018, p. 549). Em vista disso, a BNCC sinaliza propor discussões a respeito do "[...] papel do conhecimento científico e tecnológico na organização social, nas questões ambientais, na saúde humana e na formação cultural, ou seja, analisar as relações entre ciência, tecnologia, sociedade e ambiente" (MEC, 2018, p. 549).

Os objetivos mencionados sinalizam para a compreensão de que a CT são construções humanas, além de explicitarem as relações CTSA. Ademais, alguns aspectos mencionados como por exemplo, a argumentação, a verificação e utilização de fontes de informações confiáveis, o posicionamento ético, a tomada de decisões tendo em vista princípios democráticos tanto em nível individual quanto coletivo, são essenciais para a formação de pessoas que atuem como cidadãos críticos, responsáveis e alfabetizados científica e tecnologicamente, propósitos contemplados pelo enfoque CTSA, reiterando o que já havíamos mencionado. Propósitos estes que devem chegar também ao espaço acadêmico, em especial, nos currículos e na prática pedagógica dos cursos de 
Licenciatura, pois como requerer que os professores atuem em uma perspectiva que se distancia da que conhecem e difere da realizada em sua formação inicial?

Contudo, mesmo diante das potencialidades e do reconhecimento das contribuições de um ensino orientado pelo enfoque CTSA, ainda há alguns desafios a serem vencidos em relação à sua implementação, tanto no que tange às questões curriculares quanto em relação à prática pedagógica e formativa dos professores. Dentre esses desafios, Auler (2007) menciona o reducionismo metodológico, no qual este enfoque é empregado unicamente como uma nova metodologia em busca de atingir a melhoria do ensino de Ciências, em vista do cumprimento de currículos prédefinidos sem a devida participação dos professores e da comunidade escolar. Neste sentido, o referido autor enfatiza que o enfoque CTS é utilizado somente com o intuito de despertar a motivação dos alunos tendo como foco o cumprimento dos programas e dos conteúdos escolares previstos.

Ao encontro dessa ideia, Fabri e Silveira (2018) entendem que trabalhar nessa perspectiva exige uma mudança na maneira como os conteúdos são desenvolvidos em sala de aula, requerendo, assim, a utilização de metodologias e ações que sejam promotoras de reflexões, de modo que estas precisam estar presentes em todas as áreas do conhecimento, por exemplo, em Matemática, Física, Química, Biologia, entre várias outras. Concordamos ainda com as autoras, quando mencionam que não é suficiente buscar fórmulas, métodos e técnicas inovadoras, se antes não ocorrer uma mudança na postura pedagógica docente, aspecto essencial para que o trabalho orientado pelo enfoque CTSA seja, de fato, efetivado.

Outros aspectos que dificultam a implementação desse enfoque no ensino são: o fato de a formação inicial dos docentes ser basicamente disciplinar, fragmentada, o que, por sua vez, consiste em um empecilho para se trabalhar com algo que exija a inter e transdisciplinaridade; suas próprias concepções e crenças epistemológicas e sociológicas acerca da natureza da Ciência; e, por fim, o receio de perder a identidade docente, o que, de certa forma, estaria ligada à compreensão que esse professor tem dos objetivos do ensino da Ciência (Membiela, 2005).

Esses pontos reforçam a necessidade de os cursos de formação inicial apresentarem maior articulação com o enfoque CTSA, de modo a proporcionar ao licenciando a compreensão dessa temática, inter-relacionando-a com sua própria realidade e desmistificando visões simplistas em relação à CTSA. Pois o professor, na maioria das vezes, tende a ensinar o que lhe foi ensinado, especialmente, quando não sabe como desenvolver uma dada metodologia ou estratégias didático-pedagógicas diferentes das realizadas no ensino tradicional ${ }^{2}$. Destarte, como exigir dele uma postura diferenciada, se a sua formação não lhe forneceu subsídios suficientes para tal?

Assim, reconhecendo que os documentos oficiais orientam os cursos de formação

2 Entendemos aqui por ensino tradicional aquele que coloca o professor como centro do processo de ensino e aprendizagem e detentor de todo o saber, cabendo ao aluno apenas assimilar passivamente o que lhe é apresentado em uma relação de transmissão/recepção do conhecimento. 
inicial de professores e sua prática pedagógica, nos direcionamos à análise dos PPC de Licenciatura em Química, os quais são elaborados em consonância com os documentos legais, caracterizando a identidade do curso e da instituição, uma vez que nestes encontram-se descritos o perfil dos formandos, as competências e habilidades a serem desenvolvidas, a estrutura do curso, os conteúdos básicos, específicos e complementares, o formato dos estágios, as atividades complementares, as formas avaliativas (CNE, 2015), enfim, orientam os aspectos necessários à formação desse profissional. Além disso, há que se considerar, os inúmeros interesses políticos e econômicos, os quais influenciam sua elaboração e implementação.

\section{Percurso metodológico da pesquisa: um desenho dos passos constitutivos desse caminhar}

A presente pesquisa constitui-se um recorte de uma pesquisa mais ampla, em nível de mestrado, a qual teve por objetivo compreender como o enfoque CTSA tem sido contemplado nos currículos dos cursos de Licenciatura em Química das Instituições públicas de Ensino Superior paranaenses. E desses currículos, nos propomos a analisar os Projetos Pedagógicos dos Cursos (PPC) de 21 instituições identificadas por meio do sistema eletrônico $e-M E C^{3}$ do Ministério da Educação, compreendendo um universo composto por seis instituições estaduais e quinze federais.

Dessa forma, após realizarmos a seleção dessas instituições, prosseguimos com a busca pelos documentos que foram analisados no estudo. Para isso, recorremos à consulta nas páginas online das referidas instituições e, em alguns casos, nos deparamos com documentos desatualizados ou não disponibilizados e procedemos, então, contato via meio eletrônico (e-mail) com o departamento de graduação solicitando o envio da documentação. Dessa forma, foi possível o acesso a todos os documentos de análise.

Alguns destes documentos (17) já encontravam-se atualizados em adequação às Diretrizes Curriculares Nacionais para a Formação Inicial em Nível Superior (cursos de licenciatura, cursos de formação pedagógica para graduados e cursos de segunda licenciatura) e para a Formação Continuada pela Resolução CNE/CP 2/2015 (DCNFP/2015). Os demais PPC (4) ainda estavam em processo de reformulação e, por conta disso, para esses casos, analisamos os vigentes. Aspecto importante de ser mencionado é o fato de que as referidas Diretrizes (DCNFP/2015), antes mesmo de serem implementadas por todos os cursos, foram revogadas pela Resolução 2/2019, a qual define as Diretrizes Nacionais para a Formação Inicial de Professores para a Educação Básica e institui a Base Nacional Comum para a Formação Inicial de Professores da Educação Básica (BNC-Formação) significando um grande retrocesso nas políticas de formação de professores (Rodrigues, Pereira, \& Mohr, 2020).

A escolha por investigar os cursos de Licenciatura em Química se deve, em especial, pelo fato de a pesquisadora ser fruto da educação pública, desde à sua formação

3 Base de dados oficial do Ministério da Educação em que consta o cadastro nacional de cursos e Instituições de Educação Superior (http://emec.mec.gov.br/). 
no Ensino Básico até a pós-graduação. Além disso, o cenário de intensos ataques à educação pública e à pesquisa, reiteram ainda mais a relevância da escolha aqui realizada. Quanto ao PPC, o escolhemos como objeto de nossa análise pelo fato de ser o documento orientador das políticas educacionais voltadas para a Formação Inicial, bem como pela constatação de poucas pesquisas (Teses e Dissertações), especificamente, na articulação do enfoque CTSA no currículo da Licenciatura em Química, o que torna necessária a promoção de reflexões acerca dessa aproximação e do que se encontra expresso nos PPC, tal qual apresentado publicamente para consulta.

A presente pesquisa constitui-se de natureza qualitativa com o desenvolvimento de um estudo documental, de modo que nosso material empírico consiste nos PPC de Licenciatura em Química já mencionados. Justificamos o caráter de nossa pesquisa como tal pelo fato de nos preocuparmos em identificar e mergulhar nas compreensões e significados já existentes, nos materiais analisados, em busca da emergência de novas compreensões acerca do objeto de estudo. O que vai ao encontro da definição de pesquisa qualitativa apresentada por Minayo (2009) ao compreender que esta se preocupa com questões muito peculiares em direção à compreensão do "[...] universo dos significados, dos motivos, das aspirações, das crenças, dos valores e das atitudes" (p. 21).

Além disso, Moraes e Galiazzi (2007) salientam que a pesquisa qualitativa tem por intento "[...] aprofundar a compreensão dos fenômenos que investiga, a partir de uma análise rigorosa e criteriosa desse tipo de informação, isto é, não pretende testar hipóteses para comprová-las ou refutá-las ao final da pesquisa; a intenção é a compreensão" (p. 11).

No que diz respeito à análise documental, Lüdke e André (1986) enfatizam que esta "[...] pode se constituir numa técnica valiosa de abordagem de dados qualitativos, seja complementando as informações obtidas por outras técnicas, seja desvelando aspectos novos de um tema ou problema" (p. 38). Assim, conforme o material é explorado, aos poucos podem despontar aspectos antes não evidenciados e interpretados pelo pesquisador. Ademais, as referidas autoras mencionam ainda que os documentos podem significar uma fonte para evidenciar e fundamentar as próprias afirmações e declarações apresentadas pelo pesquisador ao longo de todo o processo de seu estudo, não desprezando, obviamente, o contexto do qual estas informações emanam.

Desse modo, para a realização de uma análise documental, Lüdke e André (1986) mencionam que se faz necessária a observação de procedimentos metodológicos essenciais, dentre os quais: caracterizar o tipo de documento a ser utilizado ou selecionado para o estudo, escolha esta que não se dá aleatoriamente, mas é guiada por propósitos, ideias, hipóteses e pelos próprios objetivos da pesquisa; analisar e organizar os dados presentes nos documentos, o que neste estudo foi realizado por meio da Análise Textual Discursiva (ATD), fundamentada em Moraes e Galiazzi (2016).

A escolha por essa metodologia de análise de dados deveu-se, sobretudo, ao processo de construção e desconstrução envolvido, o que, por sua vez, possibilita ao pesquisador se descobrir enquanto tal, em um exercício de constantes inseguranças, 
reflexões e (re)construções. Além disso, a ATD parte sempre de um processo cíclico, que envolve um vai e vem recursivo, que ora move para o caos, ora para o estabelecimento da ordem, em busca de entender as partes para assim compreender a totalidade do fenômeno estudado e sobre ele lançar novas compreensões, que, embora sejam novas, sempre se renovarão (Moraes \& Galiazzi, 2016).

O mergulho nos documentos a partir da ATD seguindo os pressupostos de Moraes e Galiazzi (2016) se deu em três etapas principais, sendo elas: 1) Desmontagem dos textos ou unitarização - momento em que fragmentamos o material empírico e identificamos as unidades de significados à luz do enfoque CTSA e da formação inicial de professores de Química, as quais foram codificadas por meio de letras apontando o caráter da instituição, se estadual ou federal, seguido por um número referente ao documento analisado e à unidade de significado, como por exemplo, IELQ1.1; IFLQ7.3. Em seguida, identificamos as palavras-chave de cada uma das unidades de significado e lhes atribuímos títulos descritivos que expressam a ideia central da unidade, o que, por sua vez, auxilia no processo de categorização; 2) Processo de estabelecimento de relações ou categorização - etapa em que realizamos a aproximação das unidades de significados identificadas na etapa anterior, de modo a agrupar as que apresentam elementos semelhantes, originando assim as categorias, as quais foram emergindo durante o processo de análise, sendo em seguida agrupadas em diferentes níveis, primeiramente em categorias iniciais, que foram reagrupadas em categorias intermediárias e, de um último reagrupamento, resultaram as categorias finais, a partir das quais nos encaminhamos à elaboração dos metatextos; 3) Processo de captação do novo emergente - passo no qual nos direcionamos à construção dos metatextos, os quais constituem-se em um conjunto de textos que tencionam expressar compreensões tecidas ao longo da análise e os novos entendimentos apresentados pelo pesquisador.

Mediante o processo analítico dos 21 PPC de Licenciatura em Química paranaenses, identificamos 424 unidades de significado, 19 categorias iniciais, 7 intermediárias e 3 finais, as quais resultaram em 3 metatextos, de modo que, no presente texto, apresentaremos apenas um deles, o qual intitula-se: Direcionamento para a formação humanística no entretecer da formação de professores de Química e o enfoque CTSA. Assim, dois destes não serão discutidos neste trabalho, de modo que um se volta à necessidade de promover a alfabetização científica e tecnológica dos futuros professores, bem como a compreensão da natureza da Ciência, na tentativa de desmistificar visões simplistas no tocante à CT, na compreensão do trabalho científico, bem como a importância de aprender Ciências, pois as concepções e crenças epistemológicas dos professores permeiam a forma como ensinam Ciências. O outro metatexto apresenta como o enfoque CTSA tem sido incorporado de maneira explícita dentro dos PPC, isto é, se na forma de conteúdos específicos e/ou enquanto componentes curriculares, e se as estratégias citadas nos PPC podem possibilitar a implementação desse enfoque na prática da sala de aula. E por fim, o metatexto explorado neste trabalho, se volta à formação humanística e a articulação com a formação inicial de professores e o 
enfoque CTSA, cuja construção partiu de 209 unidades de significado, 10 categorias iniciais e 3 categorias intermediárias. Assim, sinalizamos que este recorte emergiu e resulta da análise dos $21 \mathrm{PPC}$, abarcando aspectos que nos direcionam à compreensão da formação profissional docente para além do domínio de conhecimentos científicos e tecnológicos, se estendendo ao desenvolvimento de atitudes e valores éticos voltados ao exercício da cidadania, a participação ativa em processos de tomadas de decisões, a resolução de problemas, a autonomia de pensamento, bem como o comprometimento e a responsabilidade socioambiental de sua atuação e o reconhecimento da função social e política desta profissão.

\section{Direcionamento para a formação humanística no entretecer da formação de professores de Química e o enfoque CTSA}

Os documentos analisados neste estudo (PPC de Licenciatura em Química das Instituições públicas de Ensino Superior paranaenses) sinalizam, em sua constituição, um olhar que reconhece a necessidade e importância de promover uma formação para além do desenvolvimento da capacidade profissional e técnica, a qual requer a integração com uma formação humanística direcionada para o exercício pleno e consciente da cidadania. Além disso, em seu processo de formação inicial, o professor deve compreender a função social de sua profissão, de modo que possa atuar para a transformação da realidade em vista de sua responsabilidade ética, política, social e ambiental.

Nesse sentido, ao voltarmo-nos aos aspectos que tangem uma formação humanística, precisamos antes compreender o significado atribuído a esses dois termos (formação e humanística), pois de acordo com Cenci e Fávero (2008), falar em uma formação não humanística constitui-se em algo contraditório, uma vez que

Toda formação, no sentido estrito do termo, teria de incidir sobre o humano e a partir de feições humanas. Formação diz respeito a um tipo de relação entre sujeitos. A rigor, não haveria sentido em falar-se de formação relativamente a objetos, nem haveria sentido em formar sujeitos segundo métodos próprios à relação sujeito-objeto. A transposição do modelo sujeito-objeto para a esfera da formação humana é, no entanto, possível e é justamente o fator que coloca em questão a ideia de uma formação humanística (p. 3, grifos nossos).

Nesse entendimento, compreendemos que a formação humanística emana e se direciona intrinsecamente ao humano, às relações humanas e, portanto, pensá-la diferentemente disso, segundo os referidos autores, nos conduziria a uma formação tecnicista, em uma relação descontextualizada e fragmentada, totalmente contrária à primeira e distante da função da educação. Como defendido por Saviani (2008), o ser humano não se constitui humano de maneira natural, ou seja, não nasce sabendo ser humano "[...] vale dizer, ele não nasce sabendo sentir, pensar, avaliar, agir; para saber querer, agir ou avaliar é preciso aprender, o que implica o trabalho educativo" (p. 7).

Considerando esses aspectos, Cenci e Fávero (2008) mencionam dois sentidos pedagógicos que nos levam à compreensão do conceito de formação, sendo eles: 1) 
concepção de formação enquanto processo e, por conseguinte, o entendimento do ser humano como um ser incompleto e em constante formação; 2) concepção voltada à formação integral do ser humano, uma vez que a promoção de uma formação humanística, de fato, não se dá em meio à fragmentação ou instrumentalização do sujeito humano.

Como nos sinaliza Freire (2011), o inacabamento ou a inconclusão do ser constitui-se uma característica essencialmente humana e vital, pois onde existe vida, o inacabamento também se faz existente. Assim, esse autor salienta que, o ser humano está em constante processo social de busca, de modo que sua presença no mundo, “[...] não é a de quem a ele se adapta, mas a de quem nele se insere. É a posição de quem luta para não ser apenas objeto, mas sujeito também da história" (Freire, 2011, p. 37, grifo do autor). Desse modo, desconsiderar totalmente a "[...] formação integral do ser humano e a sua redução a puro treino fortalecem a maneira autoritária de falar de cima para baixo. Nesse caso, falar a, que na perspectiva democrática é um possível momento do falar com, nem sequer é ensaiado" (Freire, 2011, p. 77, grifo do autor).

Como podemos verificar, formação implica intrinsecamente o desenvolvimento humano e se faz necessária pelo fato de que

Uma formação humanística teria de estar efetivamente comprometida com a preparação para a vida em sociedade, perseguindo certas dimensões fundamentais desta, tais como a dignidade pessoal, o reconhecimento do próprio valor como pessoa e do valor dos outros, o desenvolvimento da autonomia pessoal e um projeto de vida coerente e exitoso para si, o respeito aos semelhantes e ao meio ambiente, a construção de uma visão de mundo coerente e crítica, a capacidade de estabelecer vínculos sociais e de atribuir significado às ações e às coisas, uma compreensão temporalmente situada de si e da sociedade em que vive, a orientação mediante valores universais [...] (Cenci \& Fávero, 2008, p. 4, grifo nosso).

Percebemos, então, que a formação humanística requer um direcionamento fundamentado por princípios e valores éticos, os quais se constituem em dimensões essenciais para o desenvolvimento do sujeito enquanto ser humano e para sua (con) vivência em sociedade. Dessa forma, ao considerarmos a formação inicial de professores, compreendemos que os licenciandos, nesse tipo de formação, devem ser orientados, indissociavelmente, à sua atuação enquanto futuro profissional e como cidadão na Sociedade e no Meio Ambiente.

Esse tipo de formação consiste, inclusive, em uma das exigências apresentadas pelas Diretrizes Curriculares Nacionais para os Cursos de Química (CNE/CES 1.303/2001) e encontra-se presente na maioria dos PPC analisados, uma vez que estes estão em consonância com os documentos legais. Assim, as referidas Diretrizes mencionam, no que se refere à formação pessoal do licenciado em Química, que este necessita: "Ter formação humanística que lhe permita exercer plenamente sua cidadania e, enquanto profissional, respeitar o direito à vida e ao bem-estar dos cidadãos" (Parecer CNE/CES 1.303, 2001, p. 6).

Nessa direção, apresentamos alguns excertos dos documentos analisados, os quais 
apontam que o licenciado deve, no exercício de sua atuação, "Pautar-se em princípios da ética: dignidade humana, justiça, respeito mútuo, participação, responsabilidade, diálogo e solidariedade, atuando como profissionais e como cidadãos" (IELQ2.23, grifo nosso); "Atuar com ética no exercício da profissão para a construção de uma sociedade igualitária, justa e democrática" (IELQ3.20, grifo nosso); "Estar engajado na luta pela cidadania como condição para a construção de uma sociedade justa, democrática e responsável (IELQ5.16, grifo nosso)"; "Cultivar uma visão humanística para o exercício da cidadania, o respeito à vida e o zelo pelo bem-estar comum" (IFLQ16.4, grifo nosso); "Comprometer-se com a ética profissional voltada à organização democrática da vida em sociedade" (IFLQ17.21, grifo nosso); "Formação humanística, direcionada pela ética com sua relação com o contexto cultural, socioeconômico e político" (IFLQ19.12, grifo nosso). Ou seja, a atuação docente deve direcionar-se à formação para o exercício da cidadania e transformação da sociedade, o que, por sua vez, perpassa o questionamento do status quo e requer uma atuação humanística, ética e cidadã, a qual deve ser assumida por esse profissional.

Indo ao encontro do exposto, Freire (2011) é enfático ao afirmar que os docentes têm responsabilidade ética no exercício de sua profissão, além disso essa eticidade "[...] conota expressivamente a natureza da prática educativa, enquanto prática formadora" (p. 11). É importante salientar que a ética aqui tratada, não se refere à ética de obediência aos interesses capitalistas, que tenta a todo custo legitimar o status quo enquanto fruto do determinismo social, ou seja, de aceitação quase que naturalizada das desigualdades sociais existentes, mas sim a ética universal do ser humano, que condena toda e qualquer forma de exploração deste, em direção à transformação e ruptura com sistemas opressores e instrumentos de desumanização (Freire, 2011). Nesse sentido, como nos alerta Freire (2011) "Não podemos nos assumir como sujeitos da procura, da decisão, da ruptura, da opção, como sujeitos históricos, transformadores, a não ser assumindo-nos como sujeitos éticos" (pp. 12-13).

Concordamos com o referido autor ao defender a impossibilidade de se "[...] separar em dois momentos o ensino dos conteúdos da formação ética dos educandos. A prática docente que não há sem a discente é uma prática inteira. O ensino dos conteúdos implica o testemunho ético do professor" (2011, p. 64). E essa formação ética pressupõe o desenvolvimento de valores direcionados à promoção da dignidade humana, inclusive contemplados dentre os objetivos de uma educação CTS, como mencionado por Santos e Mortimer (2002).

Esses valores estão vinculados aos interesses coletivos, como os de solidariedade, de fraternidade, de consciência do compromisso social, de reciprocidade, de respeito ao próximo e de generosidade. Tais valores são, assim, relacionados às necessidades humanas, o que significa um questionamento à ordem capitalista, na qual os valores econômicos se impõem aos demais.

Será pela discussão desses valores que contribuíremos na formação de cidadãos críticos comprometidos com a sociedade (Santos \& Mortimer, 2002, p. 114). 
Dessa forma, compreendemos que não se trata de quaisquer tipos de valores, haja vista que poderíamos pensar nos valores que direcionam para a emancipação humana, mas também em valores excludentes, que regem e perpetuam o sistema vigente. Os valores a que nos referimos, ao pensarmos em uma formação humanística, se direcionam justamente àqueles que questionam as injustiças, a perpetuação de um sistema capitalista desumano, o consumismo desenfreado, a destruição do meio ambiente, em virtude de uma ganância desmedida. Tais valores devem direcionar a formação de profissionais cidadãos na busca por promover e preservar a integridade e dignidade humana e o respeito a toda forma e diversidade de vida.

Pensar de tal modo, nos leva a seguir na contramão de imposições e ideologias que com o avanço do neoliberalismo buscam transformar a educação em um produto mercadológico, no qual a escola seria a empresa, os alunos seus clientes e os professores, os articuladores responsáveis por atingirem as metas e os objetivos postos, aspectos que podem ser evidenciados na Base Comum Curricular Nacional (BNCC), cujo processo de elaboração se deu de maneira "[...] verticalizada e sem efetivo diálogo com a comunidade escolar e acadêmica" (Rodrigues et al., 2020, p. 20). Além disso, em dezembro de 2019, de modo similar, foi promulgada a Base Nacional Comum de Formação de Professores (BNCFP) (CNE, 2019), em substituição das Diretrizes Curriculares Nacionais para a Formação de Professores de 2015 (DCNFP/2015), orientando para "[...] mudanças de fundamentos, objetivos, conteúdo e estrutura da formação inicial e continuada de professores" (Rodrigues et al., 2020, p. 3) e inclusive favorece a implementação da BNCC no sistema educacional brasileiro (Rodrigues et al., 2020). Concordamos com essas autoras ao sinalizarem que há somente quatro anos essas DCNFP/2015 vem sendo implementadas, de modo que esse curto espaço de tempo mostra-se insuficiente para seu desenvolvimento e amadurecimento, o que denota ser no mínimo irresponsável tal substituição, alterando mais uma vez os direcionamentos para a formação de professores.

Isso nos evidencia a impossibilidade de distanciarmos ou isolarmos o contexto educacional, as políticas que envolvem a formação de professores, dos impasses políticos e econômicos, das relações antagônicas que afetam direta e indiretamente no direcionamento de políticas de currículo (Lopes, 2015). E ainda nos leva a refletir a respeito do tipo de educação e formação que queremos promover, se uma educação que legitima as desigualdades, ou uma educação libertadora, para a emancipação humana.

Destarte, compreendemos que a dimensão formativa dos professores encontra-se atrelada às teorias do currículo, pois o tipo de professor que se deseja formar, implícita ou explicitamente, repercute nas propostas curriculares. A esse respeito, Silva (2005, p. 15) enfatiza que essas teorias "[...], tendo decidido quais conhecimentos devem ser selecionados, buscam justificar por que 'esses conhecimentos' e não 'aqueles devem ser selecionados", ou seja, são orientadas por interesses e relações de poder.

Diante de tais apontamentos, é nítido que o processo que envolve a "[...] implementação de políticas curriculares é tão político quanto o processo de sua elaboração. Infelizmente, muitas vezes os elaboradores de políticas os veem como 
apartados e esquecem-se que os professores também as produzem" (Rodrigues et al., 2020, p. 30).

Nesse contexto, são importantes os questionamentos trazidos por Cenci e Fávero (2008), ao indagarem quais seriam as motivações que justificam a preocupação em promover uma formação humanística no âmbito da universidade e na formação de professores, seja ela inicial ou continuada. Isso, considerando que muitos são os motivos que levam as universidades a se distanciarem da dimensão humanística no processo formativo de seus profissionais (Cenci \& Fávero, 2008). Dentre esses motivos, os referidos autores mencionam: a fragmentação dos conhecimentos; a formação inteiramente técnica dos profissionais atuantes nas instituições de Ensino Superior; o aligeiramento das formações de profissionais; a concepção de imediatismo perante o cenário econômico e social que se estabeleceu profundamente nas instituições de ensino, e acrescentaríamos ainda, como já exposto, os embates políticos e econômicos aos quais o âmbito educacional está sujeito desde a Educação Básica até a Superior.

Trata-se inclusive de aspectos que as DCNFP/2015 tentaram superar ao considerarem os seguintes princípios orientadores da base comum nacional para a formação inicial e continuada de professores: “a) sólida formação teórica einterdisciplinar; b) unidade teoria-prática; c) trabalho coletivo e interdisciplinar; d) compromisso social e valorização do profissional da educação; e) gestão democrática; f) avaliação e regulação dos cursos de formação" (CNE, 2015, p. 2).

Ressaltamos que a base comum para a formação de professores mencionada pelas DCNFP/2015 muito se distancia da BNCFP/2019, uma vez que "[...] não é desta proposta de base que estamos necessária e obrigatoriamente falando" (Rodrigues et al., 2020, p. 6), até porque a primeira (DCNFP/2015) reconhece a necessidade de valorização do profissional da educação, enquanto a segunda (BNCFP/2019) mais busca desprofissionalizá-lo ao caracterizar seu trabalho de maneira simplista, culpabilizando-o pelo desempenho de seus alunos, extirpando sua autonomia, no desrespeito às diferenças, ferindo princípios constitucionais (Rodrigues et al., 2020).

Esse movimento indica um grande retrocesso nas políticas de formação de professores, pois foi, justamente, por meio dessas Diretrizes (DCNFP/2015), que ocorreu a ampliação da duração mínima dos cursos de Licenciatura e da carga horária exigida para a formação inicial, passando de 2800 horas a serem cumpridas em pelo menos 8 semestres ou 3 anos para 3200 horas com exigência do seu cumprimento mínimo em 4 anos (CNE, 2015). Isso, por sua vez, denotava certa preocupação na maneira como a formação docente vinha ocorrendo, na busca por promover uma formação mais aprofundada e menos aligeirada, que articulasse a unidade teoria-prática desde o início do curso, perpassando todos os componentes curriculares, de modo a reconhecer as especificidades necessárias ao processo formativo de professores. Necessidades estas que vão para além de uma formação teórica sólida, que obviamente é imprescindível, englobando, conforme já mencionado, também uma formação para a cidadania e, ao mesmo tempo, para a atuação profissional, jamais se distanciando de sua dimensão 
ética, social, política e humana.

Assim, concordamos com Cenci e Fávero (2008) ao salientarem que a universidade, enquanto espaço de formação, não pode deixar de assumir seu direcionamento para a formação humanística em decorrência de sua própria natureza e, por conta disso, somos levados a nos questionar acerca de dois pontos importantes, a saber: "Quais os objetivos e qual é o espaço que a formação humanística deve ocupar nos cursos da universidade, sobretudo nas licenciaturas? Que aspectos humanísticos podem ou devem ser contemplados na formação do professor e na formação dos profissionais em geral?" (p. 4).

Ao traçarem respostas para estas indagações, os referidos autores destacam como objetivos primordiais da formação humanística na universidade: ajudar o acadêmico a desenvolver sua autonomia tanto pessoal quanto intelectual; propiciar a compreensão e o aprofundamento em relação ao compromisso com sua formação e futura profissão; promover o respeito à dignidade humana, assim como o comprometimento com os valores inerentes a uma sociedade pluralista e democrática (Cenci \& Fávero, 2008). Objetivos estes que se "[...] contrastam com uma sociedade marcada por uma lógica consumista, individualista, violenta e impregnada pelo éthos da corrupção [...]" (Cenci \& Fávero, 2008, p. 5). A partir do já exposto, acrescentamos ainda, que as respostas para tais questionamentos são complexas, uma vez que necessitam considerar os desafios enfrentados no contexto educacional, o qual é atravessado por interesses políticos e econômicos, por relações de poder. Assim, é necessário refletirmos a respeito de que tipo de formação defendemos e estamos dispostos a promover tanto na Educação Básica quanto na formação de professores (Rodrigues et al., 2020).

Esses objetivos traçados para a formação humanística concatenam-se com os pressupostos do enfoque CTSA, de modo a nos direcionar para a compreensão da necessidade de desenvolver no futuro profissional, ainda em seu espaço de formação inicial, a capacidade de problematizar, analisar e apresentar posicionamentos críticos, fundamentados e reflexivos acerca dessa realidade que o cerca e que exige constantes tomadas de decisões. Para tanto, é fundamental que ele compreenda a função social da profissão docente e da própria escola, pois o modo como esse profissional a compreende permeará e se reproduzirá em sua práxis educativa, a qual deveria sempre se direcionar à emancipação humana em busca da superação dos sistemas de desigualdade, exploração e opressão.

Em consonância com essa ideia, Freire (2011) ao mencionar no tocante à atividade educativa considerando a realidade dos educandos, salienta que

No fundo, diminuo a distância que me separa das condições malvadas em que vivem os explorados, quando, aderindo realmente ao sonho de justiça, luto pela mudança radical do mundo e não apenas espero que ela chegue porque se disse que chegará. Diminuo a distância entre mim e a dureza de vida dos explorados não com discursos raivosos, sectários, que só não são ineficazes porque dificultam mais ainda a minha comunicação com os oprimidos. Com relação a meus alunos, diminuo a distância que me separa de 
suas condições negativas de vida na medida em que os ajudo a aprender não importa que saber, o do torneiro ou o do cirurgião, com vistas à mudança do mundo, à superação das estruturas injustas, jamais com vistas a sua imobilização (p. 92).

Nesse sentido, percebemos que a função ética, social e política do professor é indissociável de sua atuação profissional, pois ele pode, em face da compreensão dos aspectos mencionados, atuar enquanto um reprodutor da ideologia dominante ou, assumindo a essência humana e ética de sua profissão, intervir enquanto agente de transformação da realidade, em vista a superação das desigualdades, da exclusão e da exploração vivenciadas por seus educandos em direção às possibilidades de mudança. Assim, “[...] o papel do professor não está em revelar a realidade dos educandos, mas de ajudá-los a desvendar a realidade por si só" (Santos, 2008, p. 126), de se reconhecerem enquanto sujeitos históricos e culturais que ao intervirem nessa realidade possam transformá-la (Freire, 2011).

Em face do exposto, apresentamos fragmentos extraídos de alguns dos documentos em análise, os quais versam acerca dessa necessidade de o profissional docente compreender a função social de sua profissão: "Ser um profissional com uma visão ampla do papel do educador e seu papel para o desenvolvimento de uma sociedade mais justa e democrática" (IELQ1.4; IFLQ7.13, grifo nosso); "Cidadão responsável - que compreende seu papel transformador na sociedade em que vive, consciente da necessidade de atuar com qualidade e responsabilidade dentro de suas áreas de atuação" (IELQ2.6, grifo nosso); “Ter consciência da importância social da profissão como possibilidade de desenvolvimento social e coletivo" (IELQ2.12; IELQ3.15; IELQ5.18; IELQ6.8; IFLQ7.11; IFLQ8.9; IFLQ10.11; IFLQ11.17; IFLQ13.20; IFLQ14.24; IFLQ19.24; IFLQ20.18; IFLQ21.16, grifo nosso); “Ciente de seu papel como educador capaz de proporcionar melhoria das condições de vida da população local e regional" (IFLQ15.16, grifo nosso); "Formar o educador consciente de seu papel na formação de cidadãos sob a perspectiva educacional, científica, ambiental e social” (IFLQ17.10, grifo nosso); "Compreender-se enquanto profissional da educação consciente de seu papel na formação do cidadão e da necessidade de se tornar agente interferidor na realidade em que atua" (IFLQ17.23, grifo nosso). Além disso, a IFLQ17.15 e IFLQ20.3 (grifo nosso) menciona ainda que

A expectativa é que, ao terminar o curso, o Licenciado em Química estará, então, apto: a exercer sua atividade profissional com percepção da sua relevância para o exercício da cidadania; de sua capacidade de analisar, compreender a realidade e ser capaz de ultrapassar os obstáculos que ela apresenta; de pensar e agir na perspectiva de possibilitar as transformações políticas, econômicas, culturais e sociais.

Assim, o educador deve compreender a docência enquanto uma profissão e seu papel, tanto no que se refere à função educativa para a formação de cidadãos quanto ao desenvolvimento e à transformação da sociedade em suas várias dimensões (econômica, política, cultural, social). Isso nos direciona a outro aspecto importante, a formação crítica e reflexiva. Como nos aponta o IFLQ17.15 e IFLQ20.3, esse profissional deve ser 
capaz de analisar, compreender e refletir sobre a realidade que o cerca, os acontecimentos que o rodeiam, de modo a questionar as decisões, não as aceitando tal qual lhe são impostas, sabendo reconhecer e identificar as influências que as direcionam, assim como os interesses envolvidos.

Convém destacar que a profissão docente constantemente se depara com inúmeros desafios que emanam, na maioria das vezes, de interesses políticos e econômicos que atentam para sua desprofissionalização, a exemplo da BNCC e BNCFP/2019. Além disso, ao refletirmos a respeito da situação em que estão inseridas as escolas, espaço de atuação docente, percebe-se que estas se “[...] encontram em uma espécie de crise crônica diante das contradições que lhe são inerentes, já que são instituições que podem tanto contribuir para reprodução como para a transformação social" (Rodrigues et al., 2020, p. 2), o que tem se intensificado com o sistema político neoliberal (Rodrigues et al., 2020).

Estas constatações corroboram nossas compreensões acerca da necessidade de uma educação CTSA, pois esta tem a função principal de formar “[...] os estudantes para enfrentarem o mundo sócio-tecnológico em mudança, de modo que sejam não só profissionalmente eficientes, mas também capazes de tomarem decisões informadas e atuarem responsavelmente a nível individual e coletivo, na sociedade" (Vieira et al., 2011, p. 14).

Diante disso, compreendemos que o profissional docente não é um simples reprodutor de técnicas e procedimentos, mas é um ser pensante, formador de sujeitos também pensantes e questionadores. Profissional este que deve refletir, indagar e problematizar a própria realidade, de modo a desenvolver, em seus educandos, espírito crítico para o exercício pleno da cidadania em direção à transformação da realidade que o envolve, ou seja, como mencionado pela IFLQ15.16, visando à melhoria das condições de vida da população. Nesse sentido, segundo Santos (2011), uma educação científica para a cidadania "[...] se concretiza na medida em que os conhecimentos científicos veiculados estejam em favor das necessidades humanas e não da dominação imposta pelos sistemas econômicos e políticos" (p. 303).

Ademais, esse profissional deve apresentar a capacidade de apontar soluções para os problemas que despontam nessa realidade e ao identificá-los, instrumentalizado pelo conhecimento científico, ser capaz de intervir ativamente para sua transformação. Consideramos então que uma formação pautada nesses aspectos pode e deve direcionar e subsidiar a atuação desse profissional em sua realidade tanto educacional quanto social.

Indo ao encontro do exposto, Cenci e Fávero (2008) mencionam que a formação humanística na universidade se direciona também à inserção social do profissional por ela formado, haja vista que

Toda profissão é uma prestação de serviço à sociedade. A formação humanística está associada à ideia de que um profissional precisa ser preparado para dar conta da função social de sua profissão. Por essa razão, é fundamental auxiliá-lo no período de sua formação para que desenvolva uma postura eticamente responsável e comprometida 
com sua profissão; que tenha uma compreensão crítica e aprofundada da sociedade em que vive e onde atuará profissionalmente; que saiba dimensionar as especificidades, a natureza e as finalidades do conhecimento acadêmico; que tenha um compromisso social e político com os problemas que precisam ser coletivamente enfrentados. Toda profissão, enquanto prestação de serviço específica à sociedade, precisa ter como horizonte, além da sobrevivência e realização pessoal do profissional, o bem comum. Por essa razão, possui uma função pública, não apenas privada (Cenci \& Fávero, 2008, p. 5, grifo nosso).

Para tanto, é fundamental promover uma formação holística que contraponha uma formação fragmentada, mecânica, desatualizada e descontextualizada, pois a profissão docente requer o conhecimento e posicionamento crítico diante dos desafios que emanam da sociedade e influem direta e indiretamente no âmbito educacional e, inevitavelmente, na formação e profissão docente. Estas, por vezes, enfrentam fortes ataques movidos pela lógica neoliberal, que tenta a todo o custo descaracterizar a profissão docente e sua função social, o que tem sido evidenciado mediante a oferta de cursos aligeirados, a intervenção de órgãos privados na educação pública, a ênfase em uma formação ora tecnicista, ora pragmática, aspectos que culminam nos retrocessos que constantemente põem em xeque as conquistas alcançadas até então (Iwasse \& Branco, 2018).

Mesmo diante desse cenário, percebemos que os PPC analisados reconhecem e indicam que a formação de professores de Química deve ser ampla, de modo a capacitar esses profissionais para a atuação na Educação Básica. Neste sentido, apresentamos o excerto seguinte, o qual menciona como um dos objetivos da formação inicial:

Propiciar uma ampla formação em nível superior, de modo que os profissionais egressos sejam capazes de realizar adequadamente as atividades de docência nas disciplinas de Química no Ensino Médio, e de Ciências no Ensino Fundamental.

Entendemos como realização adequada das atividades de docência aquela em que o/a professor/a se reconheça como construto e construtor de culturas e valores, que ele/a seja capaz de reconhecer o papel do educador frente realidade social, refletindo e se posicionando acerca dessa realidade, de modo a contribuir na formação de cidadãos reflexivos e atuantes instrumentalizados pelos conhecimentos das ciências da natureza (IFLQ19.3).

Para tanto, se faz necessário que a formação de professores ocorra de maneira integrada entre os conteúdos acadêmicos e disciplinares e a formação pedagógica docente, o que nos direciona à articulação indissociável da unidade teoria-prática (Marcelo-García, 1999). Além disso, há a necessidade de promover "[...] o isomorfismo entre a formação recebida pelo professor e o tipo de educação que lhe será pedido que desenvolva" (Marcelo-García, 1999, p. 29) na realidade escolar.

Desse modo, por meio do referido excerto, reiteramos que a atuação docente não se restringe ao domínio e à ministração de conteúdos referentes à própria área, mas envolve, também, o reconhecimento do professor enquanto sujeito capaz de se 
posicionar ante os aspectos da realidade em que atua e cooperar para sua transformação. Isso se torna possível à medida que o educador contribui, por meio de suas atividades docentes, para a formação de cidadãos que, de posse dos conhecimentos científicos, sejam questionadores do status quo, reflexivos, críticos e atuantes nas tomadas de decisões.

Assim, ressaltamos que o domínio do conteúdo a ser ensinado constitui-se em uma das necessidades formativas do profissional docente (Carvalho \& Gil-Pérez, 2011); contudo, é necessário que este domine também: conhecimentos referentes à História e Filosofia das Ciências; as diferentes orientações metodológicas utilizadas na elaboração do conhecimento científico; as relações existentes entre Ciência, Tecnologia, Sociedade e, acrescentamos ainda, Ambiente; e as distintas concepções de conhecimento científico (Schnetzler, 2002).

Isso se faz necessário, por reconhecermos que a Ciência, a Tecnologia, os conhecimentos científicos construídos ao longo da história da Humanidade não se dão em um meio neutro, desconexo da realidade, mas sim desenvolvem-se em um determinado contexto envolvido por interações e influências sociais, culturais, políticas e econômicas. Contexto no qual esse profissional e também seus educandos se encontram inseridos.

Ademais, reconhecendo a realidade social e os enfrentamentos necessários para sua transformação, o PPC da IFLQ19.11 versa que o compromisso da instituição em questão,

[...] tal como preconiza seus documentos fundantes, é possibilitar a transformação das práticas sociais excludentes, por meio do desenvolvimento integral do ser humano, consciente de sua trajetória histórico-cultural, comprometido com a construção de uma sociedade que busca construir oportunidades de participação efetiva de todos os sujeitos que a compõem, e que combata o individualismo, gerador do conformismo e da exclusão.

Nesse entendimento, a formação docente, assim como a instituição que orienta a realização do curso ofertado para tal, devem assumir a função social de promover o desenvolvimento integral do ser humano, em oposição e superação a todo tipo de relação excludente. Desse modo, deve-se direcionar para a construção de uma sociedade mais democrática, em que os cidadãos possam participar efetivamente das discussões e tomadas de decisões, na busca pelo rompimento com as decisões tecnocráticas, em que somente os especialistas é que decidem os rumos que a CT devem tomar.

Considerando os aspectos mencionados, salientamos que, quando se promove uma "[...] formação profissional e técnico-científica sem formação humanística pode facilmente dar margem à indigência cultural, à incapacidade para compreender a si, os outros e o mundo em que vive, bem como a não-percepção clara do sentido de sua própria profissão" (Cenci \& Fávero, 2008, p. 5). Nesses moldes, teríamos uma formação fundamentada no conhecimento pelo conhecimento, na prática pela prática, sem considerar a trama de relações que envolvem a dimensão humana e que são inerentes 
à compreensão da própria profissão. Forma-se, assim, um profissional que se distancia da realidade e do exercício da cidadania, fechado para o mundo e para os desafios que se colocam, destituído de sensibilidade moral e social (Cenci \& Fávero, 2008). Aspectos que se opõem ao direcionamento humanístico, haja vista que a formação de profissionais requer o entrelaçamento com a formação de cidadãos, e não a divisão e o afastamento destes (Cenci \& Fávero, 2008).

Diante desse cenário, Cenci e Fávero (2008) versam que a formação humanística do licenciando deve oportunizar que os conhecimentos construídos durante seu processo formativo na graduação se traduzam tanto em sua postura de vida quanto profissional. Nesse sentido, os referidos autores consideram três diferentes níveis de formação humanística que se complementam: i) nível específico - o qual envolve conhecimentos de ética, filosofia, sociologia, psicologia, literatura, entre outros; ii) nível atitudinal que engloba a postura que vai sendo construída pelo licenciando durante seu processo formativo na graduação, o que se dá mediante seu contato com docentes e colegas; elaboração de práticas desenvolvidas no curso direcionadas à formação humanística; experiências acadêmicas e práticas sociais atreladas à sociedade e ao desenvolvimento pessoal, profissional e humano; iii) nivel institucional - que se relaciona ao ambiente formativo construído dentro do curso de graduação propriamente dito e da instituição que o oferta, englobando o incentivo em relação aos estudos; a ética e o compromisso com a atuação profissional; o desenvolvimento de valores coletivos, como o respeito, o diálogo e a corresponsabilidade; o aprimoramento mediante a formação permanente, entre outros. Esse nível é influenciado pela postura e qualificação dos docentes do curso (Cenci \& Fávero, 2008), pois como formar profissionais nessa perspectiva se os formadores se direcionarem na contramão do que é requerido para tal?

Em consonância com essa reflexão, Bastos (2010) sinaliza que a atuação docente empenhada em propiciar uma formação humanística necessita que "[...] o professor se reconheça no processo de formação ampla, não se limitando ao desenvolvimento da disciplina, na mera condição de transmissor de conhecimentos para o aluno considerado tabula rasa" (p. 106, grifo do autor), como se a educação fosse neutra e a-problemática.

Dito isto, percebemos, por meio da análise dos PPC de Química das Instituições públicas de Ensino Superior paranaenses e da discussão aqui traçada, que esses documentos, em sua maioria, contemplam a compreensão de que a formação de professores deve promover domínio dos conhecimentos específicos de sua área de atuação, contudo também deve englobar conhecimentos pedagógicos e humanísticos. Em face disso, consideramos que se a preocupação desses cursos for direcionada apenas à formação técnica, nos afastaríamos sobremaneira de uma formação para a cidadania, para a emancipação humana. Isso, por sua vez, descaracterizaria a profissionalidade docente e sua função social e política.

Desse modo, reconhecendo que não deve haver dicotomia entre formação profissional e cidadã, teoria e prática, argumentamos que os cursos de formação de professores devem pautar-se em valores éticos e humanos, direcionando-se ao 
questionamento do status quo, o que requer a problematização, análise e tomada de decisão crítica e consciente diante da realidade envolvida. Além da necessária compreensão das relações que influenciam direta e indiretamente a tétrade Ciência, Tecnologia, Sociedade e Ambiente, uma vez que estas constituem elementos presentes tanto na cotidianidade dos futuros profissionais quanto de seus educandos. Assim, o tipo de profissional que desejamos formar permeia a construção curricular e as orientações legais, o que se traduz à medida que são concretizadas na práxis educativa dos formadores de professores.

\section{Conclusões e Implicações}

Considerando o intuito deste estudo de analisar como o enfoque CTSA tem sido contemplado nos PPC de Licenciatura em Química das Instituições públicas de Ensino Superior localizadas no estado do Paraná, apresentamos o direcionamento à formação humanística como um dos aspectos implícitos identificados. Assim, verificamos que os documentos analisados apontam para a necessidade em promover uma formação para além das exigências profissionais, que contemple também valores humanos e éticos e o comprometimento socioambiental, os quais são imprescindíveis para o exercício da cidadania e a implementação do enfoque CTSA. Isso decorre do fato de que as Instituições de Ensino Superior devem ter o compromisso em formar profissionais cidadãos conscientes da função social e política de sua atuação na sociedade.

Neste sentido, os cursos de formação de professores de Química devem oportunizar aos licenciandos a discussão, análise e compreensão das relações entre Ciência, Tecnologia, Sociedade e Ambiente, de modo a desmistificar concepções ingênuas acerca delas, como, por exemplo, identificar os impactos ocasionados pela aplicação da Química na sociedade e apontar soluções para minimizá-los; romper com a imagem de uma Ciência descontextualizada, a-histórica, neutra e dogmática, ou ainda, da Tecnologia enquanto Ciência aplicada. Trata-se de uma ação necessária, haja vista que esses aspectos irão permear e orientar a maneira como o futuro professor compreende e ensina as Ciências aos seus alunos.

Dessa forma, é imprescindível que ainda nos bancos universitários os licenciandos tenham contato com o enfoque CTSA e encontrem subsídios suficientes para atuarem nessa perspectiva, na busca pela formação de cidadãos críticos, conscientes e aptos a participarem das tomadas de decisões que envolvem o desenvolvimento científico e tecnológico, questionadores do status quo e atuantes em prol do bem comum e da transformação de sua realidade.

Isso, por sua vez, requer a articulação entre a formação que se oferta, de acordo com os documentos oficiais, com a que se exige, aquela que vai ao encontro das necessidades reais que se despontam no chão da sala de aula. Em vista disso, demonstrase a urgência em superar modelos de formação tradicionais e fragmentados, que, muitas vezes, se mostram desconexos da realidade e das situações problemáticas vivenciadas na sociedade e, consequentemente, no âmbito educacional.

Nesta perspectiva, é importante sinalizarmos que o currículo dos cursos de 
Licenciatura envolve muito mais que os aspectos apresentados explicitamente em sua estrutura, como os componentes curriculares e sua organização, mas também traz consigo fatores implícitos, que expressam relações de poder, ideologias, concepções filosóficas e epistemológicas (Silva, 2005; Lopes, 2015). Destarte, podemos verificar que a compreensão acerca do currículo da formação de professores requer um olhar minucioso para além das letras que se apresentam explicitamente no papel, pois o mesmo carrega em si elementos, significados, valores da dimensão humana, desvelando assim, características de um currículo oculto.

Dito isto, reconhecemos as limitações de nosso estudo, ao se direcionar especificamente à análise do currículo prescrito (regido pelos documentos oficiais), uma vez que tal currículo não garante sua incorporação na prática da sala de aula, isto é, no currículo real. Aspecto que nos leva a elencar, como possibilidades de estudos futuros, a investigação do currículo real desses cursos por meio de entrevistas com os professores formadores, licenciandos e coordenadores, bem como a proposição de estratégias que auxiliem a implementação do enfoque CTSA na formação inicial de professores e, assim, na Educação Básica.

Investigar o currículo real se torna imprescindível, no sentido de possibilitar uma compreensão mais fundamentada de como se efetiva, na prática, o currículo prescrito, pois como alerta Santos e Mortimer (2002), as mudanças curriculares somente serão significativas e alcançarão os objetivos propostos à medida em que tais mudanças se refletirem na prática e nas concepções pedagógicas dos professores. Passadas quase duas décadas deste alerta, a efetivação do enfoque CTSA na realidade da sala de aula e na formação de professores ainda é um grande desafio.

Pensar nestas mudanças implica também a necessária compreensão da função social do ensino de Ciências, bem como o contexto educacional brasileiro, das condições de trabalho e da formação de professores, pois do contrário torna-se quase impossível pensar em um ensino de Ciências para a cidadania (Santos \& Mortimer, 2002), ancorado pelos pressupostos do enfoque CTSA. Neste sentido, conhecer as concepções de licenciandos e professores no tocante à CTS e às relações entre estas, torna-se importante uma vez que suas concepções e crenças epistemológicas podem influenciar a forma como ensinam e ensinarão Ciências aos seus alunos (Firme \& Amaral, 2011). Ressaltamos que não basta identificá-las é preciso criar espaços formativos para que sejam devidamente discutidas e problematizadas, sem deixar de considerar as dificuldades enfrentadas por estes professores no contexto de suas práticas educacionais. Portanto, mais do que teorias acerca de "o que ensinar", é fundamental propor subsídios para o "como ensinar" a partir desse enfoque, trazendo-os para o protagonismo da discussão, dos princípios e das práticas do enfoque CTSA. Afinal de contas, o docente "[...] é a principal via de acesso das relações CTS na escola, porém, para que se efetive esse papel na sua atuação profissional, ele precisa ser formado para tal, para que estes elementos estejam presentes em sua prática pedagógica" (Tolentino, 2017, p. 85).

Perante ao exposto, as pesquisas do currículo real podem possibilitar o acesso a 
resultados voltados à prática do professor, em direção ao conhecimento de como essas práticas interferem ou contribuem para a mudança de concepção dos estudantes que vivenciam ou não o desenvolvimento desse enfoque na concretude da sala de aula. E assim, poderíamos conhecer o que, como e para que isso tem sido desenvolvido na universidade e o reflexo dessas ações na escola propriamente dita. Em outras palavras, isso significa reconhecer a dimensão mais real de como o enfoque CTSA tem sido compreendido na realidade investigada, na percepção de algumas práticas bem sucedidas. Isso requer inclusive a aproximação horizontal entre escola e universidade, pois como nos alerta Bazzo (2018), os resultados das pesquisas realizadas ainda ficam muito internalizadas em alguns grupos, não chegando às escolas "[...] ou quando chegam não conseguem estabelecer qualquer relação capaz de melhorar a vida das pessoas, quero dizer, pessoas reais e não idealizadas" (p. 273).

Além do nível universitário, pesquisas acerca da elaboração e implementação de propostas interdisciplinares no ensino de Ciências que promovam a inserção do enfoque CTSA de modo a viabilizar a alfabetização científica desde os primeiros anos de escolaridade (séries iniciais do Ensino Fundamental), como os estudos realizados por Sasseron e Carvalho (2008), são fundamentais também, em outros níveis da Educação Básica. Propostas nessa perspectiva permitem criar espaços de diálogo, reflexão, tomada de decisão e resolução de problemas que permeiam o mundo físico e social, portanto, envolvem ações que visam à formação de sujeitos críticos e criativos frente aos desafios de uma educação científica e tecnológica, capazes de problematizar as relações CTSA, visando a sustentabilidade, perante às demandas econômicas e sociais, como discutem Freitas e Marques (2019).

Diante disso, reconhecemos que há ainda lacunas voltadas ao enfoque CTSA relacionadas às pesquisas acerca de sua implementação, tanto na formação de professores quanto na Educação Básica, considerando que embora sinalizado em documentos oficiais e currículos, não alcançou sua efetivação na realidade da sala de aula. Neste movimento, o presente estudo se pautou na compreensão dos PPC, suas possibilidades e/ou fragilidades quanto ao referido enfoque, e, nesse sentido, apesar de suas limitações, proporcionou, por meio das unidades de significados que emergiram dos PPC, importantes reflexões ao que tange à elaboração de programas, políticas e, até mesmo, no tocante às ações educativas que viabilizam a efetivação do referido enfoque nos cursos de Licenciatura, em vistas a uma formação humanística, como defendida neste trabalho. E, a partir dos entendimentos tecidos no currículo prescrito, vislumbra como passos futuros compreender o currículo real.

\section{Agradecimentos}

Agradecemos à CAPES pela concessão de bolsa à primeira autora e aos pareceristas da RBPEC pelo olhar minucioso e pelas contribuições que possibilitaram a lapidação deste trabalho. 


\section{Referências}

Acevedo Díaz, J. A. (1996). Cambiando la práctica docente em la enseñanza de las ciências através de CTS. Organización de Estudios Latinoamericanos para la Educación la Ciencia y la Cultura. https://www.oei.es/historico/salactsi/acevedo2.htm

Auler, D. (2002). Interações entre Ciência-Tecnologia-Sociedade no contexto da formação de professores de Ciências. (Tese de Doutorado). Universidade Federal de Santa Catarina, Florianópolis. http://repositorio.ufsc.br/xmlui/handle/123456789/82610

Auler, D. (2007). Enfoque Ciência-Tecnologia-Sociedade: Pressupostos para o contexto brasileiro. Ciência \& Ensino, 1, 1-20. http://200.133.218.118:3535/ojs/index.php/ cienciaeensino/article/viewFile/147/109

Azevedo, R. O. M., Ghedin, E., Silva-Foresberg, M. C. da, \& Gonzaga, A. M. (2013). $\mathrm{O}$ enfoque CTS na formação de professores de Ciências e a abordagem de questões sociocientíficas. In Encontro Nacional de Pesquisa em Educação em Ciências (p. 9). Águas de Lindóia, SP. http://abrapecnet.org.br/atas_enpec/ixenpec/atas/resumos/R0325-1.pdf Bastos, C. C. B. C. (2010). Ação docente e a formação crítico-humanista na universidade. In M. L. S. Szymanski, (org.), Aprendizagem e ação docente (pp. 99-109). Edunioeste.

Bazzo, W. A. (2018). Quase três décadas de CTS no Brasil: Sobre avanços, desconfortos e provocações. Revista Brasileira de Ensino de Ciência e Tecnologia, 11(2), 2018. http:// dx.doi.org/10.3895/rbect.v11n2.8427

Brandão, M. M. (2018). O descarte de resíduos químicos e as relações entre Ciência, Tecnologia e Sociedade (CTS) no ensino de Química. (Dissertação de Mestrado). Universidade Federal do Amazonas, Manaus. https://tede.ufam.edu.br/bitstream/ tede/7036/2/Disserta\%C3\%A7\%C3\%A3o_MagalyBrand\%C3\%A3o_PPGCIM.pdf

Calixto, V. dos S. (2019). Horizontes compreensivos da constituição do ser professor de química no espaço da prática como componente curricular. (Tese de Doutorado). Universidade Estadual de Maringá, Maringá. http://repositorio.ufgd.edu.br/jspui/ handle/prefix/2452

Carvalho, A. M. P., \& Pérez, D. G. (2011). Formação de professores de ciências: Tendências e inovações. 10. ed. Cortez.

Cenci, A. V., \& Fávero, A. A. (2008). Notas sobre o papel da formação humanística na universidade. Revista Pragmateia Filosófica, 2(1). http://download.upf.br/notas_ formacao_humanistica.pdf

CNE (Conselho Nacional de Educação) (2015). Resolução CNE/CP 02 de $1^{\circ}$ de julho de 2015. Define as Diretrizes Curriculares Nacionais para a formação inicial em nível superior (cursos de licenciatura, cursos de formação pedagógica para graduados e cursos de segunda licenciatura) e para a formação continuada. http:// portal.mec.gov. br/docman/agosto-2017-pdf/70431-res-cne-cp-002-03072015-pdf/file 
CNE (Conselho Nacional de Educação) (2019). Resolução CNE/CP No 2, de 20 de dezembro de 2019. Define as Diretrizes Curriculares Nacionais para a Formação Inicial de Professores para a Educação Básica e institui a Base Nacional Comum para a Formação Inicial de Professores da Educação Básica (BNC-Formação). http://portal. mec.gov.br/docman/dezembro-2019-pdf/135951-rcp002-19/file

Cortez, J., \& Del Pino, J. C. (2018). As Diretrizes Curriculares Nacionais para os Cursos de Licenciatura em Ciências da Natureza e o Enfoque CTS. Revista Brasileira de Pesquisa em Educação em Ciências, 1(2), 27-47. https://doi.org/10.28976/1984-2686rbpec201818127

Fabri, F., \& Silveira, R. M. C. F. (Orgs). (2018). Professores em ação: Ensino de Ciências para os anos iniciais em um enfoque Ciência, Tecnologia e Sociedade (CTS). São Carlos: Pedro \& João Editores.

Figueiredo, M. C. (2011). Constatações a respeito da perspectiva CTSA na formação inicial de professores de Química. (Dissertação de Mestrado). Universidade Estadual de Maringá, Maringá. http://repositorio.uem.br:8080/jspui/handle/1/4428

Firme, R. do N., \& Amaral, E. M. R. do. (2011). Analisando a implementação de uma abordagem CTS na sala de aula de química. Ciência \& Educação,17(2), 383-399. https:// dx.doi.org/10.1590/S1516-73132011000200009

Freire, P. (2011). Pedagogia da autonomia: Saberes necessários à pratica educativa, Paz e Terra.

Freitas, N. M. D. S., \& Marques, C. A. (2019). Sustentabilidade e CTS: o necessário diálogo na/para a Educação em Ciência em tempos de crise ambiental. Educar em Revista, 35(77), 265-282. https://doi.org/10.1590/0104-4060.61568

Iwasse, L. F. A., \& Branco, E. P. (2018). Neoliberalismo e Trabalho: Dilemas da formação docente no Brasil. In R. Araújo. (Org.) Trabalho e Educação: Os dilemas do ensino público no Brasil (pp. 109-125), CRV.

Lopes, A. C. (2015). Por um currículo sem fundamentos. Linhas Críticas, 21(45), 445466. http://periodicos.unb.br/index.php/linhascriticas/article/download/4581/4179

López Cerezo, J. A. (1998). Ciencia, Tecnologia y Sociedad: El estado de la cuéstión en Europa y Estados Unidos. Revista Iberoamericana de Educación, OEI, 18. https://www. researchgate.net/publication/28052448_Ciencia_tecnologia_y_sociedad_el_estado_ de_la_cuestion_en_Europa_y_Estados_Unidos

Lüdke, M., \& André, M. E. D. A. (1986). Pesquisa em educação: Abordagens qualitativas. EPU.

Magalhães, S. I. R., \& Tenreiro-Vieira, C. (2006). Educação em Ciências para uma articulação Ciência, Tecnologia, Sociedade e Pensamento crítico: Um programa de formação de professores. Revista Portuguesa de Educação, 19(2), 85-110. http://www. scielo.mec.pt/scielo.php?script=sci_abstract\&pid=S0871-91872006000200005 
Marcelo-García, C. (1999). Formação de Professores: Para uma mudança educativa. Editora Porto LDA.

MEC (Ministério da Educação) (2018). Resolução no 4, de 17 de dezembro de 2018. Institui a Base Nacional Comum Curricular na Etapa do Ensino Médio (BNCC-EM), como etapa final da Educação Básica, nos termos do artigo 35 da LDB, completando o conjunto constituído pela BNCC da Educação Infantil e do Ensino Fundamental, com base na Resolução CNE/CP no 2/2017, fundamentada no Parecer CNE/CP nº 15/2017. 2018. http://portal.mec.gov.br/docman/dezembro-2018-pdf/104101-rcp004-18/file

Membiela, P. (2005). Reflexión desde la experiencia sobre la puesta en práctica de la orientación Ciencia-Tecnología-Sociedad en la enseñanza científica. Educación Química, 16(3), 404-409. http://dx.doi.org/10.22201/fq.18708404e.2005.3.66103

Minayo, M. C. S. (org.). (2001). Pesquisa Social: Teoria, método e criatividade. 18. ed. Vozes.

Moraes, R., \& Galiazzi, M. do C. (2007). Análise textual discursiva. 2. ed. Unijuí.

Moraes, R., \& Galiazzi, M. do C. (2016). Análise Textual Discursiva. 3.ed. Unijuí.

Moreno Rodríguez, A. S. (2015). Educação química com enfoque CTS para a formação cidadã: Caminhos percorridos nas licenciaturas da UPN e da FURG (Colômbia-Brasil). (Dissertação de Mestrado). Universidade Federal do Rio Grande, Rio Grande. http:// repositorio.furg.br/handle/1/4878

München, S. (2016). A inserção da perspectiva CTS na formação inicial de professores de Química: implicações para o desenvolvimento profissional docente. (Tese de Doutorado). Universidade Federal de Santa Maria, Porto Alegre. https://repositorio.ufsm.br/ bitstream/handle/1/3557/MUNCHEN,\%20SINARA.pdf?sequence=1\&isAllowed=y

Niza, S. (1997). Formação Cooperada - Ensaio de Auto-Avaliação dos Efeitos da Formação no Projecto Amadora. Educa e Movimento da Escola Moderna Portuguesa.

Nunes, A. O. (2010). Abordando as relações CTSA no ensino da química a partir das crenças e atitudes de licenciandos: Uma experiência formativa no sertão nordestino. (Dissertação de Mestrado). Universidade Federal do Rio Grande do Norte, Natal. https:// repositorio.ufrn.br/jspui/handle/123456789/16059

Parecer CNE/CES 1.303. (2001). Diretrizes Nacionais Curriculares para os Cursos de Química. Diário Oficial da União. http://portal.mec.gov.br/cne/arquivos/pdf/CES1303. pdf

Rodrigues, L. Z., Pereira, B., \& Mohr, A. (2020). O Documento "Proposta para Base Nacional Comum da Formação de Professores da Educação Básica" (BNCFP): Dez Razões para Temer e Contestar a BNCFP. Revista Brasileira de Pesquisa em Educação em Ciências, 20, 1-39. https://doi.org/10.28976/1984-2686rbpec2020u139 
Santos, R. C. da S. (2017). Ciência-Tecnologia-Sociedade: Suas interrelações e seu ensino nas concepções de licenciando em Química. (Dissertação de Mestrado). Universidade Federal de Sergipe, São Cristóvão. https://ri.ufs.br/handle/riufs/5128

Santos, W. L. P. (2007). Contextualização no ensino de ciências por meio de temas CTS em uma perspectiva crítica. Ciência \& Ensino, 1(especial), 1-12. http://143.0.234.106:3537/ ojs/index.php/cienciaeensino/article/view/149/120

Santos, W. L. P. (2008). Educação científica humanística em uma perspectiva freireana: resgatando a função do ensino de CTS. Alexandria: revista de educação em ciência e tecnologia, 1(1), 109-131. https://dialnet.unirioja.es/servlet/articulo?codigo=6170687

Santos, W. L. P. (2011). A Química e a formação para a cidadania. Educación química, 22(4), 300-305. http://www.scielo.org.mx/scielo.php?script=sci_arttext\&pid=S0187893X2011000400004

Santos, W. L. P. dos, \& Mortimer, E. F. (2002). Uma análise de pressupostos teóricos da abordagem C-T-S (Ciência-Tecnologia-Sociedade) no contexto da educação brasileira. Ensaio Pesquisa em Educação em Ciências, 2(2), 110-132. https://doi.org/10.1590/198321172000020202

Sasseron, L. H., \& de Carvalho, A. M. P. (2008). Almejando a alfabetização científica no ensino fundamental: A proposição e a procura de indicadores do processo. Investigações em ensino de ciências, 13(3), 333-352. https://www.if.ufrgs.br/cref/ojs/index.php/ienci/ article/view/445

Saviani, D. Escola e Saber Objetivo na Perspectiva Histórico-Crítica. (2008). In D. Saviani, Pedagogia Histórico-Crítica: Primeiras aproximações (pp. 5-10). Autores Associados.

Schnetzler, R. P. (2002). A pesquisa em ensino de química no Brasil: conquistas e perspectivas. Química Nova, 25(1), 14-24. http://dx.doi.org/10.1590/S010040422002000800004

Silva, M. A. A. da. (2016a). Ciência, Tecnologia e Sociedade, Experimentação e formação inicial de professores de Química: Explorando possibilidades. (Dissertação de Mestrado). Universidade Estadual do Sudoeste da Bahia, Jequié. http://www2.uesb.br/ppg/ppgecfp/ wp-content/uploads/2017/03/Mara-A-Alves-da-Silva.pdf

Silva, R. L., Almeida, E. dos S., Nascimento, E. S. do, \& Prudêncio, C. A. V. (2019). Professores de Química em Formação Inicial: $O$ que Pensam e Dizem sobre as Relações entre Meio Ambiente, Ciência, Tecnologia e Sociedade. Revista Brasileira de Pesquisa em Educação em Ciências, 19, 537-563. https://doi.org/10.28976/19842686rbpec2019u537563

Silva, T. do N. (2016b). Análise da inserção de questões ambientais no currículo de formação de professores de Química. (Dissertação de Mestrado). Universidade Federal Rural de Pernambuco, Recife. http://www.tede2.ufrpe.br:8080/tede2/handle/tede2/7445 
Silva, T. T. da. (2005). Documentos de identidade: Uma introdução às teorias do currículo (2. ed.). Autêntica.

Strieder, R. B., Silva, K. M. A., Fernandes Sobrinho, M., \& Santos, W. L. P. (2016). A educação CTS possui respaldo em documentos oficiais brasileiros? ACTIO: Docência em Ciências, 1(1), 87-107, 2016. http://dx.doi.org/10.3895/actio.vln1.4795

Tolentino, P. C. (2017). Os estudos Ciência, Tecnologia e Sociedade e a Prática como Componente Curricular: Tensões, desafios e possibilidades na formação de professores nas Ciências Biológicas. (Tese de Doutorado). Universidade Federal de Santa Catarina, Florianópolis. https:// repositorio.ufsc.br/handle/123456789/186146

Trivelato, S. L. F. (1999). A formação de professores e o enfoque CTS. Pensamiento Educativo, 24 (julio 1999), 201-234. https://pensamientoeducativo.uc.cl/files/journals/2/articles/149/ public/149-374-1-PB.pdf

Vieira, R. M., \& Martins, I. P. (2005). Formação de professores principiantes do ensino básico: suas concepções sobre ciência-tecnologia-sociedade. Revista Iberoamericana de Ciencia, Tecnología y Sociedad, 2(6), 101-121.

Vieira, R. M., Tenreiro-Vieira, C., \& Martins, I. P. (2011). A educação em ciências com orientação CTS - atividades para o ensino básico. Areal Editores.

Vilches, A., Gil-Pérez, D., \& Praia, J. De CTS a CTSA: Educação por um futuro sustentável. In W. P. Santos, D. Auler (Orgs.) CTS e Educação científica, desafio, tendências e resultados de pesquisa (pp. 161-184), Editora Universidade de Brasília (UdB).

Rosilene dos Santos Oliveira

${ }^{10}$ https://orcid.org/0000-0003-2699-7657

Universidade Estadual de Maringá

Programa de Pós-Graduação em Educação para a Ciência e a Matemática, Maringá, Paraná, Brasil rosiscientist@gmail.com

Neide Maria Michellan Kiouranis

${ }^{\circ}$ https://orcid.org/0000-0002-1279-9994

Universidade Estadual de Maringá

Programa de Pós-Graduação em Educação para a Ciência e a Matemática Maringá, Paraná, Brasil nmmkiouranis@gmail.com

Submetido em 28 de janeiro de 2020

Aceito em 19 de agosto de 2020

Publicado em 28 de setembro de 2020 